Khairunnisa, I.A.N · A.S. Dwi P. • S.N. Hadi

\title{
Pengaruh bahan organik berbasis gulma paitan dan pupuk NPK terhadap sifat kimia tanah, pertumbuhan, dan hasil tomat pada Ultisols
}

\author{
Effect of organic matters made from Tithonia diversifolia and NPK \\ fertilizer on soil chemical properties, growth, and yield of tomato in \\ Ultisols
}

Diterima : 20 Maret 2019/Disetujui : 22 Desember 2019 / Dipublikasikan : 31 Desember 2019

CDepartment of Crop Science, Padjadjaran University

\begin{abstract}
This research aims to know effect of organic matters of Tithonia diversifolia weeds and NPK fertilizer to soil chemical properties (organic carbon, total $N$, and total $P$ ), growth, and yield of tomato in Ultisols soil. The research was conducted at Screen House of Faculty of Agriculture, Jenderal Soedirman University, Purwokerto regency, from June to September 2018. This research used $3 \times 3$ factorial treatment design. The first factor was the dosage of organic matters of Tithonia diversifolia, consisted of 3 levels: 0, 125, dan $250 \mathrm{~g} /$ plant. The second factor was the dosage of NPK fertilizer, consisted of 3 levels: 0, 3.61, and $5.42 \mathrm{~g} /$ plant. All of treatment combinations were allocated to the experimental unit that used Randomized Block Design and was replicated 3 times. The variables observed were organic $C$, total $N$, total $P$, growth, and yield of tomato. Observational data were analyzed by F test, then Duncan's Multiple Range Test. The results showed that dosage $250 \mathrm{~g} /$ plant of organic matter of Tithonia diversifolia improved soil chemical properties, and affected significantly to growth, and yield variable likes number of leaves, wide of leaves, number of fruit, and fruit fresh weight. Dosage $5.42 \mathrm{~g} /$ plant of NPK fertilizer improved soil chemical properties, and affected significantly to all variables of growth, and yield, except root fresh weight. Combination of Tithonia diversifolia organic matter dosage $250 \mathrm{~g} /$ plant and $5,42 \mathrm{~g} /$ plant NPK fertilizer improved soil chemical properties and affected significantly to leaves area.
\end{abstract}

Keywords: Tithonia diversifolia · NPK fertilizer • Tomato · Ultisols

\footnotetext{
Dikomunikasikan oleh Anni Yuniarti dan Koko

Tampubolon

Khairunnisa, I.A.N · A.S. Dwi P. · S.N. Hadi

Fakultas Pertanian, Universitas Jenderal Soedirman

Jl. Dr. Soeparno No. 61 Purwokerto

Korespondensi: sapto.hadi@unsoed.ac.id
}

Sari. Penelitian ini bertujuan untuk mengetahui pengaruh bahan organik gulma paitan dan pupuk NPK terhadap sifat kimia tanah (C organik, N, dan $P$ total), serta pertumbuhan dan hasil tomat pada Ultisols. Penelitian dilaksanakan di screen house Fakultas Pertanian, Universitas Jenderal Soedirman, Purwokerto, pada bulan Juni sampai September 2018. Penelitian ini menggunakan rancangan perlakuan faktorial $3 \times 3$. Faktor pertama adalah bahan organik tumbuhan paitan, terdiri atas 3 taraf, yaitu 0, 125, dan $250 \mathrm{~g} /$ tanaman. Faktor kedua adalah dosis NPK, terdiri atas 3 taraf, yaitu 0; 3,61; dan 5,42 g/tanaman. Seluruh kombinasi perlakuan dialokasikan ke dalam unit percobaan dengan menggunakan Rancangan Acak Kelompok yang diulang 3 kali. Variabel yang diamati meliputi $\mathrm{C}$ organik, $\mathrm{N}$ total, $\mathrm{P}$ total, serta pertumbuhan dan hasil tomat. Data dianalisis dengan uji F, dilanjutkan dengan Duncan's Multiple Range Test. Hasil penelitian menunjukkan bahwa bahan organik tumbuhan paitan dengan dosis 250 $\mathrm{g} /$ tanaman cenderung memperbaiki sifat kimia tanah, serta berpengaruh terhadap pertumbuhan dan hasil tomat seperti jumlah daun, luas daun, bobot segar buah per tanaman sebesar $43,29 \%$ dari kontrol, dan jumlah buah sebesar $54,26 \%$ dari kontrol. Pupuk NPK dengan dosis 5,42 g/tanaman cenderung berpengaruh terhadap sifat kimia tanah, serta berpengaruh nyata semua variabel pertumbuhan dan hasil kecuali bobot segar akar. Kombinasi bahan organik tumbuhan paitan dengan dosis $250 \mathrm{~g} /$ tanaman dan pupuk NPK dengan dosis 5,42 $\mathrm{g} /$ tanaman cenderung berpengaruh terhadap sifat kimia tanah dan berpengaruh nyata terhadap variabel luas daun.

Kata kunci: Tithonia diversifolia - Pupul NPK • Tomat · Ultisols 


\section{Pendahuluan}

Tomat digolongkan ke dalam tanaman hortikultura yang banyak digunakan untuk bahan masakan, bahan baku industri saus tomat, dikonsumsi dalam keadaan segar, diawetkan dalam kaleng, dan berbagai macam bahan makanan bergizi tinggi lainnya (Kartika et al, 2013). Produksi tomat di Indonesia pada tahun 2013 mencapai 992.780 ton. Tahun 2014, produksi tomat mengalami penurunan menjadi 895.163 ton (Nuryana, 2015). Tahun 2015 produksi tomat mengalami penurunan kembali menjadi 877.792 ton dan di tahun 2016 mengalami kenaikan menjadi 883.233 ton (Badan Pusat Statistika, 2018).

Keseimbangan antara produksi dan konsumsi tanaman tomat dapat dilakukan dengan memperluas areal pertanian yang belum dimanfaatkan manusia, salah satunya menggunakan Ordo Ultisols yang mempunyai bahan organik rendah (Munir, 1996). Ultisols umumnya mempunyai permeabilitas tanah yang sangat rendah, drainase buruk, ruang pori makro yang sangat sedikit sehingga aerasi tanah sangat rendah. Ultisols juga memiliki reaksi tanah yang masam, kapasitas pertukaran kation rendah, kejenuhan basa rendah, serta kejenuhan Al yang tinggi bersifat racun bagi tanaman (Yulnafatmawita et al., 2014).

Salah satu alternatif yang dilakukan untuk memperbaiki sifat Ultisols adalah pemupukan (Sipayung et al., 2014). Ketersediaan pupuk anorganik sering menjadi kendala bagi petani dan penggunaan secara terus menerus dengan dosis yang lebih tinggi dari rekomendasi akan berdampak negatif pada kesuburan tanah (Prasetyo et al., 2014). Untuk itu, penggunaan pupuk organik dinilai menjadi solusi terbaik bagi perbaikan sifat Ultisols.

Sumber bahan organik dapat berasal dari kotoran hewan, sisa tanaman, pupuk hijau, sampah kota, limbah industri. Bahan organik ini dijadikan kompos untuk dapat diaplikasikan (Hartatik, 2007). Bahan yang dapat digunakan sebagai kompos salah satunya adalah gulma paitan (Tithonia diversifolia). Paitan adalah salah satu jenis gulma tahunan yang tumbuh subur di pinggir jalan (Prasetyo et al., 2014).

Hasil penelitian sebelumnya menunjukkan, gulma paitan mengandung 3,3 - 5,5\% N, 0,2 0,5\% P, dan 2,3 - 5,5\% K (Pramudika et al., 2014). Penelitian Simanihuruk dan Resi menunjukkan bahwa paitan dapat mengurangi penggunaan pupuk kimia sintetik terhadap tanaman padi (Nuryana, 2015).

Penelitian ini bertujuan untuk mengetahui pengaruh bahan organik gulma paitan terhadap sifat kimia tanah serta pertumbuhan dan hasil tomat pada Ultisols, mengetahui pengaruh pupuk NPK terhadap sifat kimia tanah serta pertumbuhan dan hasil tomat pada Ultisols, serta mengetahui kombinasi terbaik antara bahan organik gulma paitan dan pupuk NPK terhadap sifat kimia tanah serta pertumbuhan dan hasil tomat pada Ultisols.

\section{Bahan dan Metode}

Penelitian dilaksanakan di screen house Fakultas Pertanian, Universitas Jenderal Soedirman, Purwokerto. Persiapan dan analisis dilaksanakan di Laboratorium Ilmu Tanah, Laboratorium Agronomi dan Hortikultura, dan Laboratorium Agroekologi Fakultas Pertanian Universitas Jenderal Soedirman. Penelitian dilaksanakan pada bulan Juni sampai dengan September 2018.

Bahan yang digunakan pada penelitian meliputi Ultisols dari Desa Srowot, Kabupaten Banyumas, Provinsi Jawa Tengah, media persemaian (tanah : arang sekam: pupuk kandang = 1:1:1), benih tomat varietas Servo F1 (East West Seed), gulma paitan dari daerah Purwokerto, pupuk NPK (PT Meroke Jaya), EM4 (PT Songgolangit Persada), starter alami (Damayanti; Laboratorium Agroekologi), dan polibag.

Alat yang digunakan pada penelitian meliputi sendok, pisau, ember, timbangan analitik merk Excellent scale dan MAXXIS MT366, terpal, meteran, penggaris, hand sprayer, ajir, rafia, kertas millimeter blok, termohigrometer merk HTC-1 termo hygro, $\mathrm{pH}$ tanah merk B-One type BZD 295, lux meter merk Light Meter type HS1010, kamera, kertas label, dan alat tulis.

Penelitian ini menggunakan rancangan perlakuan faktorial $3 \times 3$. Faktor pertama adalah bahan organik gulma paitan, terdiri atas 3 taraf, yaitu 0, 125, dan $250 \mathrm{~g} /$ tanaman. Faktor kedua adalah dosis NPK dengan dosis rekomendasi $100 \mathrm{~kg} / \mathrm{ha}$, terdiri atas 3 taraf, yaitu 0, 3,61 dan $5,42 \mathrm{~g} /$ tanaman. Seluruh kombinasi perlakuan dialokasikan ke unit percobaan dengan menggunakan Rancangan Acak Kelompok yang diulang 3 kali. Variabel yang diamati meliputi C organik, $\mathrm{N}$ total, $\mathrm{P}$ total, tinggi tanaman, jumlah 
daun, luas daun, jumlah buah, bobot segar buah, bobot segar akar, dan bobot segar tanaman. Data dianalisis dengan uji F, dilanjut dengan Duncan's Multiple Range Test.

\section{Hasil dan Pembahasan}

Pengaruh Perlakuan terhadap Sifat Kimia Tanah. Pengaruh perlakuan yang dilakukan dalam penelitian meliputi $\mathrm{C}$ organik, $\mathrm{N}$ total dan P total.

C organik. Berdasarkan Gambar 1, Corganik dengan pemberian bahan organik gulma paitan cenderung meningkat. Hal ini terjadi karena adanya penambahan bahan organik dari bahan organik gulma paitan yang diberikan. Penambahan C-organik yang terdapat dalam bahan organik gulma paitan disebabkan oleh dekomposisi yang melepaskan sejumlah senyawa karbon sebagai penyusun utama dari bahan organik. Oleh karena itu, penambahan bahan organik gulma paitan berarti menambah kadar C-organik tanah. Hal ini sesuai dengan pernyataan Arifiati et al. (2017), bahwa penambahan bahan organik berupa kompos dalam tanah tentunya mampu meningkatkan kandungan C-organik dalam tanah.

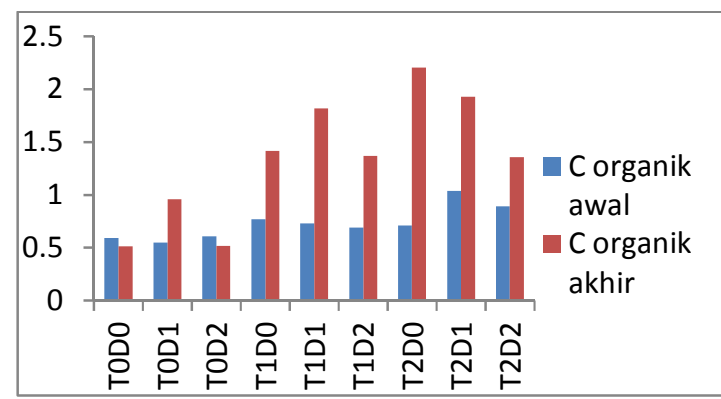

Gambar 1. Pengaruh perlakuan bahan organik gulma paitan dan NPK terhadap C organik. T0: tanpa paitan, T1: paitan $125 \mathrm{~g} /$ tanaman, T2: 250 g/tanaman, D0: tanpa NPK, D1: NPK 3,61 $\mathrm{g} /$ tanaman, D2: 5,42 g/tanaman.

N Total. Berdasarkan Gambar 2, N total akhir pada perlakuan tanpa bahan organik gulma paitan dan bahan organik gulma paitan $250 \mathrm{~g} /$ tanaman cenderung menurun, sedangkan pemberian bahan organik gulma paitan $125 \mathrm{~g}$ /tanaman meningkat. Menurunnya unsur $\mathrm{N}$ total akhir disebabkan unsur $\mathrm{N}$ terserap oleh tanaman untuk pertumbuhan tanaman dan sebagian menguap atau tercuci, sedangkan meningkatnya $\mathrm{N}$ total akhir diduga karena adanya unsur $\mathrm{N}$ dalam tanah dari pemberian bahan organik tumbuhan paitan. Hal ini sesuai dengan pernyataan Hardjowigeno (2010), bahwa hilangnya unsur $\mathrm{N}$ dari tanah karena digunakan oleh tanaman atau mikroorganisme untuk pertumbuhan dan $\mathrm{N}$ dalam bentuk $\mathrm{NO}_{3}^{-}$(nitrat) mudah tercuci oleh air. Rosmarkam dan Yuwono (2002) menyatakan bahwa bahan organik merupakan sumber nitrogen yang utama di dalam tanah. unsur hara $\mathrm{N}$ tidak diperoleh dari hasil pelapukan batuan, melainkan berasal dari hasil pelapukan bahan organik.

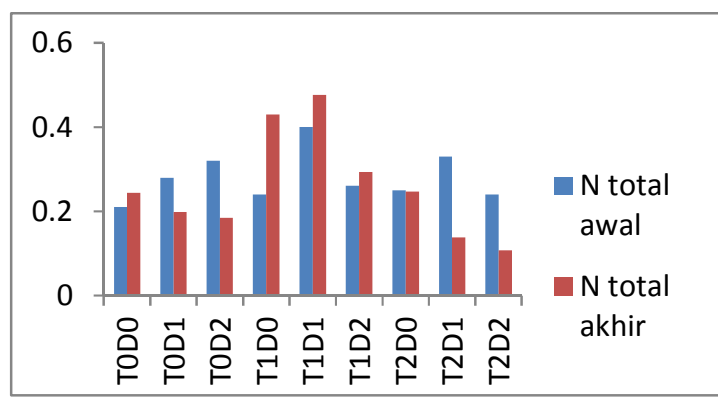

Gambar 2. Pengaruh perlakuan bahan organik gulma paitan dan NPK terhadap N total.

P Total. Berdasarkan Gambar 3, P total akhir cenderung menurun dibandingkan $\mathrm{P}$ total awal pada semua perlakuan. Hal ini kemungkinan terjadi karena unsur $\mathrm{P}$ total terserap oleh tanaman untuk pertumbuhan seperti pembentukan bunga dan buah. Terserapnya unsur $\mathrm{P}$ oleh tanaman dapat terlihat pada variabel hasil tanaman seperti jumlah buah dan bobot buah yang menunjukkan hasil yang baik. Menurut Hardjowigeno (2010), unsur P di dalam tanah yang berasal dari bahan organik, pupuk buatan, serta mineral dalam tanah, memiliki fungsi dalam pembelahan sel, pembentukan albumin, mempercepat pematangan memperkuat batang, serta membantu pembentukan bunga, buah dan biji.

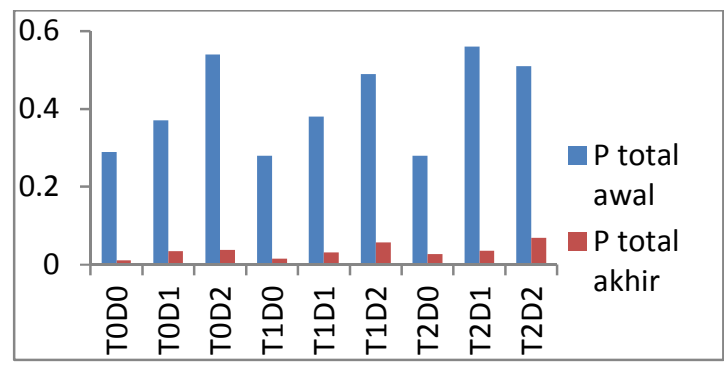

Gambar 3. Pengaruh perlakuan bahan organik gulma Paitan dan NPK terhadap P total 
Pengaruh Perlakuan terhadap pertumbuhan dan Hasil Tomat

Hasil sidik ragam pengaruh bahan organik gulma paitan, dosis NPK, serta interaksi antara kedua faktor tersebut disajikan pada Tabel 1.

Berdasarkan hasil sidik ragam, perlakuan bahan organik tumbuhan paitan tidak berpengaruh nyata pada variabel tinggi tanaman dan bobot segar akar, berpengaruh sangat nyata pada variabel luas daun, bobot segar buah per tanaman dan jumlah buah, serta berpengaruh nyata pada variabel jumlah daun dan bobot segar tanaman. Perlakuan dosis NPK berpengaruh sangat nyata pada variabel luas daun, bobot segar buah per tanaman dan jumlah buah, berpengaruh nyata pada variabel tinggi tanaman dan jumlah daun, serta tidak berpengaruh nyata pada variabel bobot segar akar dan bobot segar tanaman. Hasil sidik ragam juga menunjukkan adanya interaksi pengaruh bahan organik tumbuhan paitan dan pupuk NPK pada variabel luas daun

Tabel 1. Hasil sidik ragam pengaruh organik gulma paitan, dosis NPK, serta kombinasi organik gulma paitan dan dosis NPK.

\begin{tabular}{clcccc}
\hline \multirow{2}{*}{ No. } & \multicolumn{2}{c}{ Variabel } & \multicolumn{3}{c}{ Uji F } \\
\cline { 3 - 5 } & & $\mathbf{T}$ & $\mathbf{D}$ & $\mathbf{T} \times \mathbf{D}$ \\
\hline 1 & Tinggi Tanaman $(\mathrm{cm})$ & $\mathrm{tn}$ & $\mathrm{n}$ & $\mathrm{tn}$ \\
2 & Jumlah Daun (helai) & $\mathrm{n}$ & $\mathrm{n}$ & $\mathrm{tn}$ \\
3 & Luas Daun $\left(\mathrm{cm}^{2}\right)$ & $\mathrm{sn}$ & $\mathrm{sn}$ & $\mathrm{sn}$ \\
4 & Bobot Segar Akar $(\mathrm{g})$ & $\mathrm{tn}$ & $\mathrm{tn}$ & $\mathrm{tn}$ \\
5 & Bobot Segar Tanaman $(\mathrm{g})$ & $\mathrm{n}$ & $\mathrm{tn}$ & $\mathrm{tn}$ \\
& Bobot Segar Buah per & & & \\
6 & Tanaman (g) & $\mathrm{sn}$ & $\mathrm{sn}$ & $\mathrm{tn}$ \\
7 & Jumlah Buah & $\mathrm{sn}$ & $\mathrm{sn}$ & $\mathrm{tn}$ \\
\hline
\end{tabular}

Keterangan: $\mathrm{T}=$ bahan organik gulma paitan, $\mathrm{D}=$ dosis NPK, $\mathrm{T} \times \mathrm{D}=$ interaksi bahan organik gulma paitan dan dosis NPK, $\mathrm{tn}=$ tidak berpengaruh nyata, $\mathrm{n}=$ berpengaruh nyata, $\mathrm{sn}=$ berpengaruh sangat nyata

Tinggi Tanaman. Berdasarkan Tabel 2, bahan organik tumbuhan paitan sampai dengan dosis $250 \mathrm{~g} /$ tanaman belum mampu berpengaruh terhadap tinggi tanaman, sedangkan dosis NPK berpengaruh terhadap tinggi tanaman. Perlakuan dosis NPK 5,42 g/tanaman mampu meningkatkan tinggi tanaman tomat sebesar 13,76\% dibandingkan dengan kontrol. Hal ini diduga karena kebutuhan nutrisi tanaman tersedia pada pupuk NPK. Hal ini sesuai dengan pernyataan Saberan et al. (2014), bahwa tanaman akan tumbuh dengan baik apabila unsur hara yang dibutuhkannya tersedia cukup dan unsur hara tersebut tersedia dalam bentuk yang dapat diserap oleh tanaman. Salisbury dan Ross (1995) menyatakan bahwa tinggi tanaman dapat dipengaruhi oleh faktor internal (hormon) dan lingkungan (unsur hara dan cahaya).

Tabel 2. Pengaruh bahan organik tumbuhan paitan dan dosis NPK terhadap tinggi tanaman tomat $(\mathrm{cm})$.

\begin{tabular}{lcccc}
\hline Bahan & \multicolumn{3}{c}{$\begin{array}{c}\text { Pupuk NPK } \\
\text { (g/tanaman) }\end{array}$} & Rerata \\
$\begin{array}{c}\text { Organik } \\
\text { Paitan } \\
\quad(\mathrm{g} /\end{array}$ & 0 & 3,61 & 5,42 & \\
\cline { 2 - 4 } $\begin{array}{c}\text { tanaman) } \\
0\end{array}$ & & & & \\
\hline 125 & $28,80 \mathrm{a}$ & $34,74 \mathrm{~b}$ & $55,56 \mathrm{e}$ & 39,70 \\
250 & $49,88 \mathrm{~cd}$ & $55,13 \mathrm{e}$ & $63,44 \mathrm{f}$ & 56,15 \\
\hline Rerata & $52,10 \mathrm{de}$ & $56,52 \mathrm{e}$ & $57,15 \mathrm{e}$ & 55,25 \\
\hline
\end{tabular}

Keterangan : angka yang diikuti huruf kecil pada kolom yang sama dan angka kapital pada baris yang sama menunjukan berbeda nyata pada uji DMRT dengan taraf nyata 5\%, (-) tidak terjadi interaksi.

Jumlah Daun. Berdasarkan Tabel 3, bahan organik gulma paitan berpengaruh terhadap jumlah daun. Bahan organik gulma paitan dengan dosis $250 \mathrm{~g} /$ tanaman mampu meningkatkan jumlah daun sebesar 29,88\% dibandingkan kontrol. Peningkatan jumlah daun dipengaruhi oleh nutrisi yang diserap tanaman. Hal ini sesuai dengan pernyataan Prasetyo et al. (2014), bahwa aplikasi dosis kombinasi kompos kotoran sapi dan paitan menunjukkan berbeda nyata pada jumlah daun dan luas daun karena unsur $\mathrm{N}$ berperan besar pada pertumbuhan tanaman tomat.

Tabel 3. Pengaruh bahan organik gulma paitan dan dosis NPK terhadap jumlah daun tanaman tomat (helai).

\begin{tabular}{|c|c|c|c|c|}
\hline \multirow{2}{*}{$\begin{array}{c}\text { Bahan } \\
\text { Organik } \\
\text { Paitan } \\
\text { (g/ } \\
\text { tanaman) }\end{array}$} & \multicolumn{3}{|c|}{$\begin{array}{l}\text { Pupuk NPK } \\
\text { (g/tanaman) }\end{array}$} & \multirow[t]{2}{*}{ Rerata } \\
\hline & 0 & 3,61 & 5,42 & \\
\hline$\overline{0}$ & 99,54 & 165,65 & 212,98 & $159,39 \mathrm{a}$ \\
\hline 125 & 183,39 & 199,94 & 240,04 & $207,79 a$ \\
\hline 250 & 202,39 & 241,59 & 237,96 & $227,31 \mathrm{~b}$ \\
\hline Rerata & 161,77 & $202,40 \mathrm{~A}$ & 230,32 B & $(-)$ \\
\hline
\end{tabular}

Keterangan : angka yang diikuti huruf kecil pada kolom yang sama dan angka kapital pada baris yang sama menunjukan berbeda nyata pada uji DMRT dengan taraf nyata 5\%, (-) tidak terjadi interaksi. 
Pemberian pupuk NPK berpengaruh terhadap jumlah daun. Pemberian dosis pupuk NPK sebesar 5,42 g/tanaman meningkatkan jumlah daun sebesar 29,76\% dibandingkan kontrol. Menurut Firmansyah et al. (2017), tomat memerlukan unsur hara terutama $\mathrm{N}, \mathrm{P}$, dan $\mathrm{K}$ karena digunakan untuk pertumbuhan vegetatif, yaitu perkembangan akar, batang, dan daun. Jumlah daun yang lebih banyak memungkinkan penyerapan hara yang lebih optimum.

Luas daun. Tabel 4, menunjukkan bahwa adanya pengaruh interaksi antara pemberian bahan organik gulma paitan dan dosis NPK. Pemberian bahan organik gulma paitan dengan dosis $125 \mathrm{~g} /$ tanaman dan NPK dengan dosis 5,42 $\mathrm{g} /$ tanaman meningkatkan luas daun dibandingkan pemberian bahan organik tumbuhan paitan dengan dosis $250 \mathrm{~g} /$ tanaman dan tanpa bahan organik tumbuhan paitan.

Pertambahan luas daun terjadi karena unsur $\mathrm{N}$ yang ada pada bahan organik tumbuhan paitan dan pupuk NPK berperan besar pada pertumbuhan tanaman, seperti yang dinyatakan Cabral (2004), bahwa pemberian pupuk organik yang tinggi dapat menambah unsur hara mikro dan juga dapat meningkatkan ketersediaan unsur hara dalam tanah bagi tanaman terutama unsur $\mathrm{N}$ yang fungsi utamanya ialah untuk perkembangan vegetatif tanaman. Simatupang (2014) menyatakan bahwa luas daun berkaitan dengan fotosintesis. Meningkatnya luas daun dipengaruhi oleh jumlah hara didapatkan.

Tabel 4. Pengaruh bahan organik gulma paitan dan dosis NPK terhadap luas daun tanaman tomat $\left(\mathrm{cm}^{2}\right)$.

\begin{tabular}{lcccc}
\hline Bahan & \multicolumn{3}{c}{$\begin{array}{c}\text { Pupuk NPK } \\
\text { Organik }\end{array}$} & \multicolumn{3}{c}{ (g/tanaman) } & Rerata \\
\cline { 2 - 4 } $\begin{array}{c}\text { Paitan } \\
(\mathrm{g} /\end{array}$ & 0 & 3,61 & 5,42 & \\
tanaman) & & & & \\
\hline 0 & 67,7296 & 79,2963 & 89,7574 & $78,9278 \mathrm{a}$ \\
125 & 78,1463 & 85,9574 & 92,6741 & 85,5926 a \\
250 & 81,9778 & 84,2389 & 81,7889 & $82,6685 \mathrm{a}$ \\
\hline Rerata & 75,9512 A & 83,1642 A & $88,0735 \mathrm{~B}$ & $(-)$ \\
\hline Keterangan : angka yang diikuti huruf pada kolom \\
dan baris yang sama menunjukan berbeda nyata \\
pada uji DMRT dengan taraf nyata 5\%, (+) terjadi \\
interaksi.
\end{tabular}

Bobot Segar Tanaman. Tabel 5 menunjukkan pemberian bahan organik gulma paitan berpengaruh terhadap bobot segar tanaman, sedangkan pupuk NPK belum berpengaruh terhadap bobot segar tanaman. Bahan organik gulma paitan dengan dosis 250 $\mathrm{g} /$ tanaman mampu meningkatkan bobot buah segar sebesar 42,73\% dibandingkan kontrol. Hal ini diduga kandungan unsur hara yang dibutuhkan tanaman tomat tersedia pada bahan organik tumbuhan paitan. Paitan mampu meningkatkan bobot segar tanaman karena mudah terdekomposisi dan dapat menyediakan nitrogen dan unsur hara lainnya bagi tanaman (Lestari, 2016).

Tabel 5. Pengaruh bahan organik gulma dan dosis NPK terhadap bobot segar tanaman tomat (g).

\begin{tabular}{llcll}
\hline $\begin{array}{c}\text { Bahan } \\
\text { Organik } \\
\begin{array}{c}\text { Paitan } \\
\text { (g/ }\end{array}\end{array}$ & \multicolumn{3}{c}{$\begin{array}{c}\text { Pupuk NPK } \\
\text { (g/tanaman) }\end{array}$} & Rerata \\
\cline { 2 - 4 } tanaman) & 0 & 3,61 & 5,42 & \\
\hline 0 & & & & \\
125 & 68,00 & 230,75 & 360,17 & $212,42 \mathrm{a}$ \\
250 & 271,25 & 297,83 & 390,75 & $301,69 \mathrm{ab}$ \\
Rerata & 298,00 & 376,50 & 361,75 & $370,89 \mathrm{~b}$ \\
& & & A & \\
\hline
\end{tabular}

Keterangan : angka yang diikuti huruf kecil pada kolom yang sama dan angka kapital pada baris yang sama menunjukan berbeda nyata pada uji DMRT dengan taraf nyata 5\%, (-) tidak terjadi interaksi.

Bobot Segar Akar. Berdasarkan analisis Tabel 6, perlakuan bahan organik gulma paitan, dosis NPK dan kombinasi keduanya terhadap bobot segar akar belum mampu mempengaruhi pertumbuhan dan hasil tomat. Hal ini diduga karena tanah Ultisol sebagai media tanam tomat memiliki tingkat liat yang tinggi, sehingga pertumbuhan akar kurang optimal. Menurut Munawar (2011), tanah yang memiliki liat tinggi menyebabkan tanah lengket dan keras yang akan menghambat pergerakan akar. Hal lain yang menyebabkan tidak berpengaruhnya perlakuan terhadap bobot segar akar tanaman tomat adalah adanya pembagian fotosintat.

Bobot Segar Buah Per Tanaman. Tabel 7, menunjukkan pemberian bahan organik gulma paitan dan pupuk NPK berpengaruh sangat nyata terhadap bobot segar buah, tetapi tidak terjadi interaksi antara pemberian bahan organik gulma paitan dan dosis NPK. Bahan organik gulma paitan dengan dosis $250 \mathrm{~g} /$ tanaman mampu meningkatkan bobot segar buah sebesar 43,29\% dan NPK 5,42 g/tanaman mampu meningkatkan $43,60 \%$ dibandingkan kontrol. Kandungan unsur 
hara pada paitan dan pupuk NPK berupa N, P dan $\mathrm{K}$ dapat menunjang pertumbuhan dan hasil tanaman terutama unsur K. Menurut Koheri (2015), unsur kalium diperlukan tanaman setelah nitrogen dalam metabolisme tanaman sebagai katalisator yang mengubah protein menjadi asam amino dan penyusun karbohidrat.

Tabel 6. Pengaruh bahan organik gulma paitan dan dosis NPK terhadap bobot segar akar tanaman tomat $(\mathrm{g})$.

\begin{tabular}{lcccc}
\hline $\begin{array}{c}\text { Bahan } \\
\text { Organik }\end{array}$ & \multicolumn{3}{c}{$\begin{array}{c}\text { Pupuk NPK } \\
\text { (g/tanaman) }\end{array}$} & Rerata \\
\cline { 2 - 4 } $\begin{array}{c}\text { Paitan } \\
(\mathrm{g} / \text { tana }\end{array}$ & 0 & 3,61 & 5,42 & \\
$\quad$ man $)$ & & & & \\
\hline 0 & 13,33 & 11,28 & 26,58 & $17,06 \mathrm{a}$ \\
125 & 25,33 & 17,50 & 22,08 & $21,64 \mathrm{a}$ \\
250 & 28,33 & 26,67 & 25,25 & $26,75 \mathrm{a}$ \\
\hline Rerata & $22,33 \mathrm{~A}$ & $18,48 \mathrm{~A}$ & $24,64 \mathrm{~A}$ & $(-)$ \\
\hline
\end{tabular}

Keterangan : angka yang diikuti huruf kecil pada kolom yang sama dan angka kapital pada baris yang sama menunjukan tidak berbeda nyata pada uji DMRT dengan taraf nyata 5\%, (-) tidak terjadi interaksi.

Tabel 7. Pengaruh bahan organik tumbuhan paitan dan dosis NPK terhadap bobot segar buah per tanaman tomat $(\mathrm{g})$.

\begin{tabular}{|c|c|c|c|c|}
\hline \multirow{2}{*}{$\begin{array}{c}\text { Bahan } \\
\text { Organik } \\
\text { Paitan } \\
(\mathrm{g} / \text { tanam } \\
\text { an) } \\
\end{array}$} & \multicolumn{3}{|c|}{$\begin{array}{l}\text { Pupuk NPK } \\
\text { (g/tanaman) }\end{array}$} & \multirow[t]{2}{*}{ Rerata } \\
\hline & 0 & 3,61 & 5,42 & \\
\hline 0 & 27,61 & 129,50 & 153,39 & $103,50 \mathrm{a}$ \\
\hline 125 & 121,28 & 158,42 & 252,28 & $177,32 \mathrm{ab}$ \\
\hline 250 & 160,78 & 201,47 & 185,28 & $182,51 \mathrm{~b}$ \\
\hline Rerata & $103,22 \mathrm{~A}$ & $63,13 \mathrm{AB}$ & $196,98 \mathrm{~B}$ & $(-)$ \\
\hline
\end{tabular}

Keterangan : angka yang diikuti huruf kecil pada kolom yang sama dan angka kapital pada baris yang sama menunjukan berbeda nyata pada uji DMRT dengan taraf nyata 5\%, (-) tidak terjadi interaksi.

Jumlah Buah. Tabel 8, menunjukkan bahwa pemberian bahan organik gulma paitan dan dosis pupuk NPK berpengaruh nyata terhadap jumlah buah, tetapi tidak terjadi interaksi antara bahan organik gulma paitan dan pupuk NPK. Bahan organik gulma paitan dengan dosis 250 $\mathrm{g} /$ tanaman mampu meningkatkan jumlah buah sebesar $54,26 \%$ dan bahan organik gulma paitan dengan dosis $125 \mathrm{~g} /$ tanaman mampu meningkatkan jumlah buah sebesar 37,46\% dibandingkan kontrol. NPK 5,42 g/tanaman mampu meningkatkan jumlah buah sebesar
43,74\% dan NPK 3,61 g/tanaman mampu meningkatkan jumlah buah sebesar 41,86\% dibandingkan kontrol. Unsur $\mathrm{K}$ yang tersedia dapat meningkatkan jumlah buah. Lingga dan Marsono (2007) menjelaskan bahwa pada fase generatif seperti jumlah buah dan berat buah tidak lepas dari unsur hara makro $\mathrm{P}$ dan $\mathrm{K}$. Unsur $\mathrm{P}$ berfungsi mempercepat pembungaan, pemasakan biji, dan buah. Unsur K berfungsi untuk memperkuat daun, bunga dan buah tidak mudah gugur.

Tabel 8. Pengaruh bahan organik gulma paitan dan dosis NPK terhadap jumlah buah per tanaman tomat (buah).

\begin{tabular}{lcccc}
\hline \multicolumn{1}{c}{$\begin{array}{c}\text { Bahan } \\
\text { Organik } \\
\begin{array}{c}\text { Paitan } \\
\text { (g/tanaman) }\end{array}\end{array}$} & \multicolumn{4}{c}{$\begin{array}{c}\text { Pupuk NPK } \\
\text { (g/tanaman) }\end{array}$} \\
\cline { 2 - 4 } Rerata \\
\hline 0 & 0 & 3,61 & 5,42 & \\
125 & 1,33 & 3,61 & 5,03 & $3,32 \mathrm{a}$ \\
250 & 3,86 & 5,33 & 6,75 & $5,31 \mathrm{~b}$ \\
\hline Rerata & 5,42 & 9,31 & 7,08 & $7,27 \mathrm{c}$ \\
\hline
\end{tabular}

Keterangan : angka yang diikuti huruf kecil pada kolom yang sama dan angka kapital pada baris yang sama menunjukan berbeda nyata pada uji DMRT dengan taraf nyata 5\%, (-) tidak terjadi interaksi.

\section{Kesimpulan}

1. Bahan organik tumbuhan paitan dengan dosis $250 \mathrm{~g} /$ tanaman cenderung memperbaiki sifat kimia tanah, serta berpengaruh terhadap pertumbuhan dan hasil tomat seperti jumlah daun, luas daun, bobot segar buah per tanaman sebesar $43,29 \%$ dari kontrol, dan jumlah buah sebesar $54,26 \%$ dari kontrol.

2. Pupuk NPK dengan dosis $5,42 \mathrm{~g} /$ tanaman cenderung berpengaruh terhadap sifat kimia tanah, serta berpengaruh nyata terhadap semua variabel pertumbuhan dan hasil kecuali bobot segar akar.

3. Kombinasi antara bahan organik gulma paitan dengan dosis $250 \mathrm{~g} /$ tanaman dan pupuk NPK dengan dosis 5,42 $\mathrm{g} /$ tanaman cenderung berpengaruh terhadap sifat kimia tanah (Corganik, $\mathrm{N}$ total, dan $\mathrm{P}$ total) serta berpengaruh nyata terhadap variabel luas daun.

\section{Ucapan Terima Kasih}

Ucapan terimakasih disampaikan kepada Laboratorium Agroekologi, Laboratorium Ilmu 
Tanah, serta Laboratorium Agronomi dan Hortikultura Fakultas Pertanian Universitas Jenderal Soedirman atas dukungan yang diberikan selama penelitian.

\section{Daftar Pustaka}

Arifiati, Aminah, Syekhfani, dan Y. Nuraini. 2017. Uji Efektivitas Perbandingan Bahan Kompos Paitan (Tithonia diversifolia), Tumbuhan Paku (Dryopteris filixmas), dan Kotoran Kambing Terhadap Serapan N Tanaman Jagung Pada Inceptisol. Jurnal Tanah dan Sumberdaya Lahan. 2 (4): 543-552.

Badan Pusat Statistik. 2018. Badan Pusat Statistik. https://www.bps.go.id site/resultTab. diakses pada 07 april 2018 pukul 05.03 WIB.

Cabral. F. 2004. The Effect Of Organic Residues From Different Sources On Soil Properties, Fruit Production, and Mineral Composition Of Pepper Crop. J. Nutrient and Carbon Cycling in Sutainable Plant-Soil System. Portugal. p. 165-168.

Firmansyah, I., M. Syakir, dan L. Lukman. 2017. Pengaruh Kombinasi Dosis Pupuk N, P, dan K Terhadap Pertumbuhan dan Hasil Tanaman Terung (Solanum melongena L.). J. Hort. 1 (27) : 69-78.

Hardjowigeno, S. 2010. Ilmu Tanah. Akademika Pressindo. Jakarta. $285 \mathrm{hlm}$.

Hartatik, W. 2007. Tithonia diversifolia Sumber Pupuk Hijau. Warta Penelitian dan Pengembangan Pertanian. 29 (5) : 3-5

Kartika, E., Z. Gani dan D. Kurniawan. 2013. Tanggapan Tanaman Tomat (Lycopersicum esculentum Mill) Terhadap Pemberian Kombinasi Pupuk Organik Dan Pupuk Anorganik. Jurnal Bioplantae. 2 (3) : 122 : 131.

Koheri, A., Mariati dan T. Simanungkalit. 2015. Tanggap Pertumbuhan dan Produksi Bawang Merah (Allium ascalonicum L.) Terhadap Waktu Aplikasi dan Kosentrasi Pupuk KNO3. Jurnal Agroteknologi. 3 (1) : 206-213.

Lestari, S. A. D. 2016. Pemanfaatan Paitan (Tithonia diversifolia) sebagai Pupuk Organik pada Tanaman Kedelai. Iptek Tanaman Pangan. 11 (1): 49 -56.

Lingga dan Marsono. 2007. Edisi Revisi. Petunjuk Penggunaan Pupuk. PT. Penebar Swadaya. Jakarta. 160 hlm.
Munawar, A. 2011. Kesuburan Tanah dan Nutrisi Tanaman. IPB Press. Bogor. $250 \mathrm{hlm}$.

Munir. 1996. Tanah-Tanah Utama Indonesia Karakteristik, Klasifikasi dan Pemanfatannya. PT Dunia Pustaka Jaya. Jakarta. 346 hlm.

Nuryana, F. I. 2015. Respons Beberapa Varietas Tomat (Lycopersicon Esculentum Mill.) Terhadap Penanaman Kacang Hias (Arachis Pintoi Krap. \& Greg.) Dalam Sistem Olah Tanah Minimum. Skripsi. Departemen Agronomi dan Holtikultura Fakultas Pertanian IPB. Bogor. $42 \mathrm{hlm}$.

Pramudika, G., S. Y. Tyasmoro dan N. E. Suminarti. 2014. Kombinasi Kompos Kotoran Sapi Dan Paitan (Tithonia diversifolia L.) Pada Pertumbuhan Dan Hasil Tanaman Terung (Solanum melongena L.). Jurnal Produksi Tanaman. 2 (3) : 253-259.

Prasetyo, A. Dwi, E. E. Nurlaelih dan S. Y. Tyasmoro. 2014. Pengaruh Kombinasi Kompos Kotoran Sapi Dan Paitan (Tithonia diversifolia L.) Terhadap Produksi Tomat (Lycopersicum esculentum Mill). Jurnal Produksi Tanaman. 2 (6) : 510-516.

Rosmarkam, A dan N.W, Yuwono, 2002. Ilmu Kesuburan Tanah. Kanisius.Yogyakarta. 219 hlm.

Saberan, N., A. Rahmi, dan H. Syahfari. 2014. Pengaruh Pupuk NPK Pelangi dan Pupuk Daun Grow Team M Terhadap Pertumbuhan dan Hasil Tanaman Tomat (Lycopersicon esculentum L. Mill) Varietas Permata. J. AGRIFOR. 1 (13) : 67-74.

Salisbury, F.B dan C.W Ross. 1995. Fisiologi Tumbuhan Jilid 1. Bandung: ITB.

Simatupang, P. 2014. Pengaruh Dosis Kompos Paitan (Tithonia diversifolia) Terhadap Pertumbuhan Dan Hasil Kol Bunga Pada Sistem Pertanian Organik. Skripsi. Fakultas Pertanian Universitas Bengkulu. 53 hlm.

Sipayung, E.S., G. Sitanggang, dan M.M.B. Damanik. 2014. Perbaikan sifat fisik dan kimia tanah Ultisol Simalingkar B Kecamatan Pancur Batu dengan pemberian pupuk organik Supernasa dan rockphosphit serta pengaruhnya terhadap produksi tanaman jagung (Zea mays L.). J. Agroekoteknologi, 2(2): $393-403$.

Yulnafatmawita, D. Detafiano, P. Afner dan Adrinal. 2014. Dynamics of physical properties of ultisol under corn cultivation in wet tropical area. International Journal on Advanced Science Engineering Information Technology. 4 (5) : 11-16. 
Ariyanti, M. $d k k .:$ Respons pertumbuhan tanaman kelapa belum menghasilkan terhadap pemberian air kelapa dan asam humat 